African Crop Science Journal by African Crop Science Society is licensed under a Creative Commons Attribution 3.0 Uganda License. Based on a work at www.ajol.info/ and www.bioline.org.br/cs DOI: http://dx.doi.org/10.4314/acsj.v26i2.6

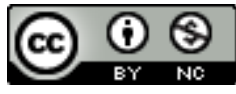

\title{
EFFECT OF MATURITY STAGES ON SEED QUALITY OF TWO TOMATO ACCESSIONS
}

\author{
R. TETTEH, L.M. ABOAGYE, R. DARKO and E.A. OSAFO
}

CSIR-Plant Genetic Resources Research Institute, P.O. Box 7, Bunso, Eastern Region, Ghana. Corresponding author: rashbalm@yahoo.com, rashiedt62@gmail.com

(Received 6 March 2018; accepted 20 April, 2018)

\begin{abstract}
Seed maturation is one of the main factors that determine vegetable seed quality, which is a prerequisite for successful germination and seedling emergence. The objective of this study was to evaluate maturity stages and their effect on seed quality of tomato (Solanum lycopersicum) accessions. A field and laboratory studies were conducted at the experimental site of CSIR-Plant Genetic Resources Research Institute, Bunso, Ghana using two tomato accessions, GH 9207 and GH 9305. Seeds were extracted from fruits harvested at four maturity stages, namely, initially ripe, half ripe, fully ripe and rotten. Before seed extraction, data on fruit characteristics, including fruit diameter, fruit length and fruit weight were recorded. Seed quality was assessed by 100 -seed weight, seed vigour and germination percentage. Tomato accession GH 9207 had a larger fruit diameter and weight than GH 9305. Both accessions did not differ in 100-seed weight among treatments. Higher seed vigour and germination percentage was observed in tomato accession GH 9207 than in GH 9305. Seeds extracted at the initially ripe stage had the least vigour in both accessions. Tomato seeds of high vigour and germination can be obtained from fruits harvested at half ripe, fully ripe and rotten stages irrespective of the accession.
\end{abstract}

Key Words: Germination percentage, maturity stage, seed quality, seed vigour, Solanum lycopersicum

\section{RÉSUMÉ}

La maturation est l'un des facteurs principaux qui détermine la qualité des graines des cultures maraîchères, qui est un prérequis pour une germination réussie et une émergence des plantules. L'objectif de cette étude était d'évaluer les stades de maturité et leur effet sur la qualité des graines des accessions de la tomate (Solanum lycopersicum). Des essais de champ et de laboratoire ont été conduits sur le site expérimental de CSIR-Institut de Recherches sur les Ressources Génétiques, Bunso, Ghana en utilisant deux accessions de tomate GH9207 et GH9305. Les graines ont été extraites de fruits récoltés pendant quatre stades de maturité, dénommées, initialement mûr, moitié mûr, totalement mûr et pourri. Avant l'extraction des graines, les données ont été collectées sur les caractéristiques de fruits, y compris le diamètre du fruit, la longueur de fruit et le poids du fruit. La qualité des graines a été évaluée par le poids de 100 graines, lavigueur des graines et le pourcentage de germination. L'accession GH 9207 de tomate a eu des fruits de diamètre et de poids plus grands que GH 9305. Toutes les deux accessions sont différentes sur le poids des 100 graines entre les traitements. Des graines de grande vigueur et de haut pourcentage de germination ont été observées sur l'accession GH 9207 que sur GH 9305. Les graines extraites au stade de maturation initiale ont la plus faible vigueur sur les deux accessions. Les graines de vigueur élevée et de fort taux de germination peuvent être obtenues sur les fruits récoltés aux stades de moitié mûr, totalement mûr et pourri selon l'accession.

Mots Clés: Pourcentage de germination, stade de maturité, qualité de la graine, vigueur de la graine, Solanum lycopersicum 


\section{INTRODUCTION}

Tomato (Solanum lycopersicum) belongs to the family Solanaceae. It is one of the most popularly produced and extensively consumed vegetable crops in the world (Grandillo et al., 1999). The fresh fruits are eaten in salads and sandwiches and as salsa; while the processed ones are consumed dried or as pastes, preserves, sauces, soups, juices, and drinks (Alam et al. 2007; Beckles et al., 2012). Worldwide, annual production of tomatoes is estimated at 170.8 million metric tonnes, with China accounting for $31 \%$ of the total, followed by India, the United States and Turkey as the major producers (FAOSTAT, 2016). In Ghana, tomato is the most important crop in recently established dry season gardens in Northern and Upper Regions and in Southern Volta Regions (Obeng-Ofori et al., 2007). In spite of its extensive cultivation, covering an area of 44,000 ha in 2012, tomato yields are still low, about $7.5 \mathrm{t}$ $\mathrm{ha}^{-1}$, compared to achievable yields of $15 \mathrm{t}$ ha $^{-1}$, giving a yield gap of 50\% (Danquah and Fulton. 2007; FAOSTAT, 2013). However, the quality of seeds used by farmers has been implicated as a possible cause (Horna et al., 2006).

Seed quality is a complex trait and is defined as the viability and vigour attribute of a seed that enables the emergence and establishment of normal seedlings under a wide range of environments (Khan et al., 2012). Several studies have shown that the occurrence of maximum seed quality during seed development differs among plant species (Pieta Filho and Ellis, 1991; Demir and Ellis, 1992b, 1993). However, production of high quality tomato seeds depends upon the timing of fruit harvest.

There are disagreements regarding the development stage when seeds acquire maximum physiological quality. Kwon and Bradford (1987) reported that germination rate and percentage of tomato seeds increased as fruits developed from green-mature to red- mature stage, and then declined from red to overripe.

Methods of seed production of Solanum sp. are highly variable (Blay et al., 1999). Some farmers extract seeds from either the first harvest, middle or at the end of the production period. Besides, the stage of ripening is also quite varied. Although some studies have been conducted on different maturity stages, a knowledge gap still exist. The objective of this study was to determine the right stage of physiological maturity for harvesting tomato fruits for high quality seed production and to ascertain whether differences in maturity stage exist between genotypes.

\section{MATERIALS AND METHODS}

Experimental site, planting material and experimental design. Two experiments, a field experiment on seed production and a laboratory evaluation on seed quality were conducted at CSIR-Plant Genetic Resources Research Institute, Bunso, Eastern Region, Ghana. Seeds of tomato (GH 9207 and GH 9305) were obtained from the same Institute. Seeds were sown on 24 April, 2017 and transplanted at 23 days after sowing. A spacing of $60 \mathrm{~cm} \mathrm{x} 60 \mathrm{~cm}$ was used. The experiment was arranged in a randomised complete block design (RCBD) and replicated three times.

Agronomic practices. During the experimental period, fertiliser NPK-15-15-15 was applied at a rate of $400 \mathrm{~kg}$ per hectare. Watering and weeding were carried out as and when necessary. Insect pests were controlled using K-optimal insecticide (Landa-cyhalothrin $15 \mathrm{~g} \mathrm{l}^{-1}$ +Acetamiprid $20 \mathrm{~g} \mathrm{l}^{-1}$ : EC) at the recommended rate of $40 \mathrm{ml}$ to 151 of water at two weeks interval.

Harvesting of fruits for seeds. Harvesting of fruits was done at different physiological maturity stages for seed extraction at 73 days after sowing (DAS) for both tomato 
accessions. Fruits were sorted into categories of four, comprising of initially ripe, half ripe, fully ripe and rotten fruits. Before seed extraction, fruits were rinsed with tap water to remove unwanted materials. Seeds were extracted manually, and air dried at ambient temperature $\left(30^{\circ} \mathrm{C}\right)$ for 7 days to attain a lower moisture content. After drying, manual cleaning of seeds was done to remove debris and infected seeds to improve on the purity and quality of seeds. Seeds were placed on silica gel to attain a constant moisture content.

Fruit characteristics and 100-seed weight. Twenty fruits were sampled from each tomato accession and weighed individually, using an electronic balance $(0.0001 \mathrm{~g})$. Fruit weight was expressed as mean fruit weight in grammes. For fruit length and diameter, twenty fruits were harvested and measured individually with a veneer calliper. Hundred seeds from each treatment were counted and weighed with an electronic balance, and this was replicated four times.

Seed vigour and germination. Seed vigour and germination test were conducted from 31 August to 19 September, 2017 in petri dishes and seed boxes (i.e. emergence). Germination test was carried out under field conditions using seed boxes, with sterilised topsoil and in the laboratory using petri dishes and filter paper. For each treatment, 50 seeds were used and replicated four times. The randomised complete block design (RCBD) and the completely randomised design were used for field and laboratory test, respectively. The first count (seed vigour) and final count (germination percentage) were established on the 5 and $14^{\text {th }}$ days, respectively. Seed germination was calculated by the following formula (ISTA, 1999):

Seed germination $(\%)=\underline{\text { Seed germinated }} \times 100$ Total seeds

Data analysis. Statistical analyses was conducted using the SPSS Statistics 21 (IBM, Chicago, IL, USA). Data were subjected to two-way ANOVA, and when the treatment means were significant, Tukey's HSD test was conducted to identify differences among treatments.

\section{RESULTS}

Figure 1 shows different maturity stages of two tomato accessions (GH 9207 and GH

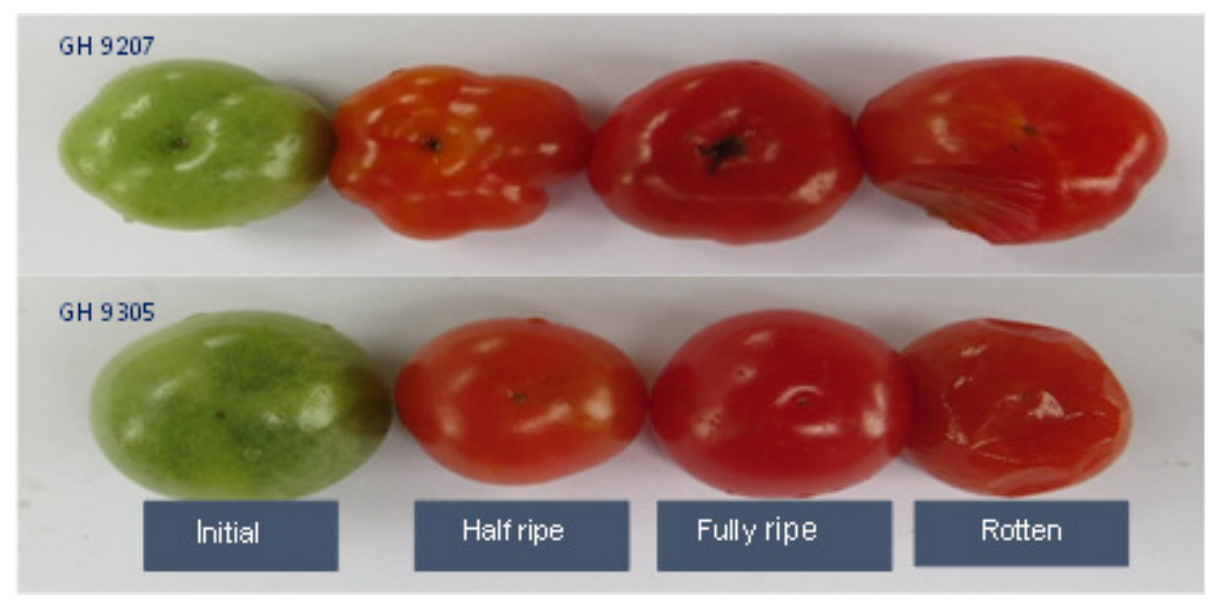

Figure 1. Different maturity stages of two tomato accessions (GH 9207 and GH 9305) at harvesting. Initially ripe $=$ Green with light red spot, Half ripe $=$ Light red/orange, Fully ripe $=$ Red, Rotten $=$ Red with decomposing texture. 
9305) at harvesting. Initially ripe fruits of tomato appeared green with light red spots, half ripe as light red or orange, fully ripe as red; and rotten as red with decomposing texture.

The fruit characteristics of two tomato accessions are shown in Table 1 . Tomato accession GH 9207 had the highest fruit diameter $(3.59 \mathrm{~cm})$, fruit weight $(18.38 \mathrm{~cm})$ and number of seeds per fruit (181.8). Both tomato accessions (GH 9207 and GH 9305) had similar fruit lengths.

The effect of maturity stage on 100-seed weight of two tomato accessions (GH 9207 and GH 9305) is shown in Table 2. Maturity stage had no significant effect on 100-seed weight of the two tomato accessions.Also, no significant interaction was observed between maturity stage and accession.

Maturity stage had a significant effect $(\mathrm{P}<0.001)$ on seed vigour (Table 3$)$. Seeds extracted at the fully ripe stage were not significantly different from seeds extracted at the half ripe and rotten stages. Seeds extracted at the initially ripe stage had the least vigour in both accessions, with GH 9305 recording the lowest. Both accessions differed significantly with GH 9207 obtaining the highest vigour in both petri-dish and seed box.

Table 4 presents the effect of maturity stage on germination of two tomato accessions. Maturity stage had a significant $(\mathrm{P}<0.001)$ effect on germination percentage. Seeds extracted at the fully ripe stage showed the highest germination, but were not significantly different from seeds extracted at the half ripe and rotten stages in both accessions. Seeds extracted at the initially ripe stage had the lowest germination percentage in accession GH 9305. Both accessions differed significantly with GH 9207 recording the highest germination percentage in both petri dish and seed box.

\section{DISCUSSION}

Maturity stage on seed vigour. Maturity stage had a significant effect on seed vigour in both tomato accessions (Table 3). Generally, low germination speed, high sensibility to stresses of seeds and seedlings during germination process, and plants with

TABLE 2. Effect of maturity stage on 100-seed weight of two tomato accessions (GH 9207 and GH 9305)

\begin{tabular}{llc}
\hline Accession & Maturity stage & 100-seed weight (g) \\
\hline GH 9207 & Initially ripe & $0.207(0.010)$ \\
& Half ripe & $0.208(0.009)$ \\
& Fully ripe & $0.209(0.016)$ \\
& Rotten & $0.202(0.020)$ \\
GH 9305 & Initially ripe & $0.213(0.009)$ \\
& Half ripe & $0.218(0.007)$ \\
& Fully ripe & $0.217(0.014)$ \\
& Rotten & $0.214(0.007)$ \\
ANOVA & Maturity stage (MS) & n.s. \\
& Accession (A) & n.s. \\
& MS x A & n.s. \\
\hline
\end{tabular}

Each value is the mean of four replicates and the standard deviation is shown in parentheses. Two-way ANOVA: n.s.= not significant

TABLE 1. Fruit characteristics of two tomato accessions (GH 9207 and GH 9305) grown in Ghana

\begin{tabular}{lcccc}
\hline Accession & Fruit diameter $(\mathrm{cm})$ & Fruit length $(\mathrm{cm})$ & Fruit weight $(\mathrm{g})$ & Number of seeds/ fruit \\
\hline GH 9207 & $3.59(0.34) \mathrm{a}$ & $2.38(0.16)$ & $18.38(3.50) \mathrm{a}$ & $181.8(29.2) \mathrm{a}$ \\
GH 9305 & $2.98(0.31) \mathrm{b}$ & $2.39(0.18)$ & $12.51(3.19) \mathrm{b}$ & $101.2(34.9) \mathrm{b}$ \\
t-test & $* *$ & n.s. & $* *$ & $* * *$ \\
\hline
\end{tabular}

Each value is the mean of twenty fruits, and the standard deviation is shown in parentheses. $\mathrm{t}$-test: $* * \mathrm{P}<0.01$, $* * * \mathrm{P}<0.001, \mathrm{n} . \mathrm{s}=$ not significant 
TABLE 3. Effect of maturity stage on seed vigour of two tomato accessions (GH 9207 and GH 9305)

\begin{tabular}{llll}
\hline Accession & Maturity stage & \multicolumn{2}{c}{ Seed vigour } \\
\cline { 3 - 4 } & & Petri dish & Seed box \\
\hline \multirow{2}{*}{ GH 9207 } & Initially ripe & $35.5(1.9) \mathrm{b}$ & $33.5(4.0) \mathrm{c}$ \\
& Half ripe & $47.3(0.5) \mathrm{a}$ & $46.8(1.5) \mathrm{a}$ \\
& Fully ripe & $47.3(1.7) \mathrm{a}$ & $47.0(2.2) \mathrm{a}$ \\
& Rotten & $46.8(2.0) \mathrm{a}$ & $48.0(0.8) \mathrm{a}$ \\
GH 9305 & Initially ripe & $19.5(3.3) \mathrm{c}$ & $17.3(2.9) \mathrm{d}$ \\
& Half ripe & $43.3(1.3) \mathrm{a}$ & $39.5(4.9) \mathrm{bc}$ \\
& Fully ripe & $45.3(1.3) \mathrm{a}$ & $44.0(3.6) \mathrm{ab}$ \\
& Rotten & $43.8(3.9) \mathrm{a}$ & $42.0(2.7) \mathrm{ab}$ \\
ANOVA & Maturity stage (MS) & $* * *$ & $* * *$ \\
& Accession (A) & $* * *$ & $*$ \\
\hline
\end{tabular}

Each value is the mean of four replicates and the standard deviation is shown in parentheses. Two-way ANOVA: $* \mathrm{P}<0.05$, *** $\mathrm{P}<0.001$. When significant interaction between maturity stage (MS) and Accession (A) was detected, Tukey's HSD test was performed to identify significant differences among the 4 maturity stages. Values with different letters are significantly different at $\mathrm{P}<0.05$. *Seed vigour was expressed as the number of seeds germinated at first count

TABLE 4. Effect of maturity stage on germination percentage of two tomato accessions (GH 9207 and GH 9305)

\begin{tabular}{llll}
\hline Accession & Maturity stage & \multicolumn{2}{c}{ Germination $(\%)$} \\
\cline { 3 - 4 } & & Petri dish & Seed box \\
\hline GH 9207 & Initially ripe & $76.50(4.43) \mathrm{b}$ & $76.50(5.74) \mathrm{b}$ \\
& Half ripe & $99.00(1.15) \mathrm{a}$ & $98.50(1.91) \mathrm{a}$ \\
& Fully ripe & $98.50(1.91) \mathrm{a}$ & $96.00(2.82) \mathrm{a}$ \\
& Rotten & $97.00(2.00) \mathrm{a}$ & $97.00(2.00) \mathrm{a}$ \\
GH 9305 & Initially ripe & $45.50(7.18) \mathrm{c}$ & $45.00(5.29) \mathrm{c}$ \\
& Half ripe & $95.00(2.58) \mathrm{a}$ & $94.50(2.52) \mathrm{a}$ \\
& Fully ripe & $96.00(1.63) \mathrm{a}$ & $98.50(1.91) \mathrm{a}$ \\
& Rotten & $94.50(1.91) \mathrm{a}$ & $95.50(1.91) \mathrm{a}$ \\
ANOVA & Maturity stage (MS) & $* * *$ & $* * *$ \\
& Accession (A) & $* * *$ & $* * *$ \\
& MS x A & $* * *$ & $* * *$ \\
\hline
\end{tabular}

Each value is the mean of four replicates and the standard deviation is shown in parentheses. Two-way ANOVA: *** $\mathrm{P}<0.001$. When significant interaction between maturity stage (MS) and Accession (A) was detected, Tukey's HSD test was performed to identify significant differences among the 4 maturity stages. Values with different letters are significantly different at $\mathrm{P}<0.05$ 
slow, low and irregular growth or with less root development, are typical characteristics of seed with low physiological potential (Marcos-Filho, 2005). The observed differences between the initially ripe and other treatments in the study could be attributed to immature seeds due to improper seed filling. Although no significant difference was observed among the half ripe, fully ripe and rotten treatments, this could be attributed to the stabilisation of dry matter translocation to the seed at maturity (Marcos Filho et al., 1994).

According to Ellis (1992) and Castro et al. (2006), the duration of the seed filling phase and environmental conditions may potentially affect the amount and quality of reserve food stored. Thus, the seed filling phase indirectly plays a vital role in successful establishment of an autotrophically growing seedling by supplying nutrition and energy and bridging the gap between germination and establishment of green cotyledons that are capable of photosynthesis. Poorter and Rose (2005) indicated that seed reserve food, frequently represented by seed mass, potentially contributes to seedling vigour as it is generally assumed that larger seeds produce more vigorous seedlings.

Although we did not observe significant difference in 100-seed weight in the present study (Table 2), seeds extracted from initially ripe stage showed lower 100-seed weight; thus, this could have accounted for its low vigour. This may have influence on establishment of initial population of plants, as well as on their adequate development, which subsequently affects crop yield (Hampton, 2002). Demir and Ellis (1992a) reported that maximum seed quality occurred after maximum seed dry matter accumulation, without recording the stage of fruit ripeness. Besides, Demir and Samit (2001) indicated that seeds of tomato should be harvested when fruits are red-firm (70 days after anthesis) for higher germination and not to the seed dry weight.
Maturity stage on seed germination. Fruits harvested at half ripe, fully ripe and rotten stage had similar physiological quality, resulting in increased seed germination (Table 4). However, the germination percentage observed at the various maturity stages were above $85 \%$, which is the recommended percentage for high quality seeds (Hay and Whitehouse, 2017). Maximum germination and vigour occurred 15 days after attainment of maximum dry mass in tomato (Kwon and Bradford, 1987). It was also verified by Demir and Ellis (1992a), for whom the highest germination percentage was obtained at 70 days after anthesis, while the maximum dry matter content occurred at 50 days after anthesis. Valdes and Gray (1998) found maximum germination of seeds from fruits harvested as early as the breaker stage of the fruit. Besides, the seeds from red-fruits germinated more rapidly and further harvest delay led to seed deterioration.

According to Doijoe (1988) and Baruah et al. (1996), the best germination is obtained from seeds extracted from red ripe tomato fruits, which is in agreement with our findings. Similarly, Belleti and Quagliotti (1991) indicated that, the highest percentage of seed germination can be obtained from full (red or yellow) coloured fruit rather than from green fruits. In comparison with other crops, Oladiran (1986) recorded a better germination in Corchorus olitorius seeds extracted from brown fruits compared to seeds from green fruits. In the present study, seeds extracted at the half ripe and rotten stages had the same physiological quality as seeds extracted at the fully ripe stage in both tomato accessions.

\section{CONCLUSION}

The present study revealed that tomato seeds of high quality can be obtained from fruits harvested at half ripe, fully ripe and rotten stages irrespective of the accession. Tomato accession GH 9207 showed higher seed quality than accession GH 9305. Seeds 
extracted at the initial stage had a germination percentage below the recommended in both tomato accessions thus indicating a lower seed quality.

\section{ACKNOWLEDGEMENT}

The authors acknowledge the Council for Scientific and Industrial Research-Plant Genetic Resources Research Institute (CSIRPGRRI) of Ghana for the facilities. We also thank Dr. Kenneth Fafa Egbadzor, Mr. Benjamin Kwakye Adu, Mr. Richard Boampong and all staff at the seed store of CSIR-PGRRI for their support during the study.

\section{REFERENCES}

Alam, T., Tanweer, G. and Goyal, G.K. 2007. Packaging and storage of tomato puree and paste. Stewart Postharvest Review 3:1-8.

Barua, H., Rahman, M. M. and Masud, M. M. 2009. Effect of storage containers environment at different storage period on the quality of chilli seed. International Journal of Sustainable Crop production 4(4):28-32.

Baruah, G.R.S., Paul, S.R. and Das, G. 1996. Effect of fruit maturity stages and drying methods on seed quality of tomato. Annals of Agricultural Research, India 17(3):331332.

Beckles, D.M. 2012. Factors affecting the postharvest soluble solids and sugar content of tomato (Solanum lycopersicum L.) fruit. Postharvest Biology and Technology 63(1): 129-140.

Belletti P. and Quagliotti, L. 1991. Tomato and pepper production in the tropics. Asian Vegetable Research and Development Center, Taiwan 4:28-41.

Blay, E., Danquah, E.Y. and Ababu, A. 1999. Effect of time of harvest, stage of fruit ripening, and post-harvest ripening on seed yield and germinability of local garden egg (Solanum gilo Radii). Ghana Journal of Agricultural Science 32(2):159-167.
Castro, J., Hodar, J. and Gomez, J. 2006. Seed size. Handbook of seed science and technology. pp. 397-427.

Danquah, E. and Fulton, T. 2007. Tomato improvement in Ghana. SOL Newsletter 17. 4pp.

Das, G. and Baruah, G.R.S. 1997. The influence of plant density on the yield and quality of Tomato. Journal of American Horticultural Science 107:282-5.

Demir, I. and Ellis, R.H. 1992a. Changes in seed quality during seed development and maturation in tomato. Seed Science Research 2(2):81-87.

Demir, I. and Ellis, R.H. 1992b. Development of pepper (Capsicum annuum L.) seed quality. Annals of Applied Biology 121(2): 385-399.

Demir, I. and Ellis, R.H. 1993. Changes in potential seed longevity and seedling growth during seed development and maturation in marrow. Seed Science Research, 3(4):247-257.

Demir, I. and Samit, Y. 2001. Seed quality in relation to fruit maturation and seed dry weight during development in tomato. Seed Science and Technology 29(2):453-462.

Doijoe, S.D. 1988. Changes in seed quality on deterioration in tomato. Progressive Horticulture 20(3-4): 253-256.

Ellis, R. 1992. Seed and seedling vigour in relation to crop growth and yield. Plant growth regulation 11(3):249-255.

FAOSTAT, 2013. Food and Agriculture Organization Statistics Global Report, 2013.

FAOSTAT, 2016. Global tomato production in 2014. UN Food and Agriculture Organization, Statistics Division.

Grandillo, S., Zamir, D., S. D. and Tanksley, S.D. 1999. Genetic improvement of processing tomatoes: A 20 years perspective. Euphytica 110(2):85-97.

Hampton, J.G. 2002. What is seed quality? Seed Science and Technology 30(1):1-10.

Hay, F.R. and Whitehouse, K.J. 2017. Rethinking the approach to viability monitoring in seed genebanks. Conservation Physiology 5(1):1-13. 
Horna, D., Melinda, S. and Jose, F.-Z. 2006. Assessing the potential economic impact of genetically modified crops in Ghana: Tomato, garden egg, cabbage and in processing tomatoes. Scientia Horticulturae 27:189-198. ISTA, 1999. International Rules for Seed Testing Rules: Seed Science and Technology. International Seed Testing Association, Zurich, Switzerland. 24pp.

Khan, N., Kazmi, R.H., Willems, L.A., Van Heusden, A.W., Ligterink, W. and Hilhorst, H.W. 2012. Exploring the natural variation for seedling traits and their link with seed dimensions in tomato. PLoS One 7(8): e43991.

Kwon, O.S. and Bradford, K.J. 1987. Tomato seed development and quality as influenced by preharvest treatment with ethephon. HortScience 22:588-591.

Marcos-filho, J. 2005. Fisiologia de sementes de plantas cultivadas. Piracicaba: Fealq, 495.

Marcos-Filho, J., Chamma, H.M.C.P., Casagrande, J.R.R. and Marcos, E.A. 1994. Effect of harvesting time on seed physiological quality, chemical composition and storability of soybeans. Scientia Agricola. Piracicaba 51(2):298-304.
Obeng-Ofori, D., Yirenkyi, D. E. and OfosuAnim, J. 2007. Vegetable and spice crop production in West Africa. The city printers limited, Accra, Ghana. 53pp.

Oladiran, J.A. 1986. Effect of storage of harvesting and seed treatment on germination, Seedling Emergence and growth in Corchorus olitorius 'Oniyanya'. Scientia Horticulturae 28(3):227-233.

Pieta Filho, C. and Ellis, R.H. 1991. The development of seed quality in spring barley in four environments. I. Germination and longevity. Seed Science Research 1(3):163177.

Poorter, L. and Rose, S.A. 2005. Lightdependent changes in the relationship between seed mass and seedling traits: A meta-analysis for rain forest tree species. Oecologia 142(3):378 387.

Valdes, V.M. and Gray, D. 1998. The influence of stage of fruit maturation on seed quality in tomato (Lycopersicon lycopersicum (L.) Karsten). Seed Science and Technology 26(2):309-318.

Yisa, P. Z., Oladiran, J. A., Kolo, D. H., Ahmed, M., Tswanya, M.N. and Nda, S.L. 2013. Behaviour of pepper cultivar (Capsicum annum) to seed development, maturation, dormancy and vigour. International Research Journal of Plant Science 4(4): 103-108. 